\title{
PENGARUH IKLIM PSIKOLOGIS TERHADAP KEPUASAN KERJA DAN ORGANIZATIONAL CITIZENSHIP BEHAVIOR DI PT. SARANA TANI PRATAMA
}

\author{
I Gede Indra Tenaya ${ }^{1}$ \\ I Gusti Made Suwandana ${ }^{2}$
}

${ }^{1,2}$ Fakultas Ekonomi dan Bisnis Universitas Udayana (UNUD), Bali, Indonesia Email: indratenaya91@gmail.com

\begin{abstract}
ABSTRAK
Organizational Citizenship Behavior merupakan perilaku pilihan yang tidak menjadi bagian dari kewajiban kerja formal seorang karyawan, namun mendukung berfungsinya organisasi tersebut secara efektif. Tujuan dari penelitian ini adalah untuk mengetahui pengaruh Iklim Psikologis terhadap Kepuasan Kerja dan Organizational Citizenship Behaviordi PT. Sarana Tani Pratama. Penelitian ini dilakukan pada karyawan PT. Sarana Tani Pratama. Sampel yang diambil sebanyak 99 karyawan. Teknik pengambilan sampel dengan random sampling, pengumpulan data dilakukan dengan penyebaran kuesioner yang menggunakan skala likert 5 poin untuk mengukur 27 item pernyataan. Teknik analisis yang digunakan adalah Path Analysis. Hasil penelitian menunjukkan bahwa iklim psikologis berpengaruh positif signifikan terhadap kepuasan kerja. Kedua, iklim psikologis berpengaruh positif signifikan terhadap organizational citizenship behavior. Ketiga, kepuasan kerja berpengaruh positif signifikan terhadap organizational citizenship behavior.
\end{abstract}

Kata kunci: iklimpsikologis, kepuasan kerja, organizational citizenship behavior

\begin{abstract}
Organizational Citizenship Behavior is the behavior of choice which does not become part of formal obligation for an employee, but support the organizational effectively. The purpose of this study is to know the influence of Psychological Climate on Job Satisfaction and Organizational Citizenship Behavior in PT. Sarana Tani Pratama. This study conducted on employees in PT. Sarana Tani Pratama. Sample was taken about 99 employees. The samplingtechnique with random sampling, data collection was done by distributing questionnaires using Likert scale 5 point to measure 27 items of statement. Analytical technique with path analysis. The result of this study indicate that psychological climate is positive and significant impact to job satisfaction. Secondary, psychological climate is positive and significant impact to organizational behavior. Third, job satisfaction is positive and significant impact to organizational citizenship behavior.
\end{abstract}

Keywords: psychological climate, job satisfaction, organizational citizenship behavior 


\section{PENDAHULUAN}

Sumber daya manusia merupakan asset dan harta yang berharga dalam sebuah organisasi (Hasibuan, 2000).Perilaku extra-role adalah perilaku dalam bekerja yang tidak terdapat pada deskripsi kerja formal karyawan tetapi sangat dihargai jika ditampilkan karyawan karena meningkatkan efektivitas dan kelangsungan hidup organisasi (Katz dalam Purba \& Seniati, 2004).Perilaku atau kinerja extra-role merupakan suatu elemen kunci yang wajib diperhatikan sebuah organisasi atau dikenal dengan istilah Organizational Citizenship Behavioryaitu perilaku melebihi apa yang telah distandarkan perusahaan (Krietner dan Kinicki, 2004). OCB dapat timbul dari berbagai macam jenis faktor dalam organisasi, dikarenakan antara lain yakni kepuasan serta komitmen (Robbin dan Judge, 2007). Ketika karyawan merasa puas terhadap hasil pekerjaannya, maka karyawan akan mengoptimalkan kinerjanya tanpa himbauan perusahan (Luthans, 1998).

Iklim kerja yang positif dalam organisasi juga harus diperhatikan agar sosialisasi antar karyawan terjalin secara baik maka akan tercipta suasana kerja yang lebih menyenangkan (Soegandhi dkk.,2013). Iklim psikologis berguna dalam menyamaratakan persepsi mengenai keadaan kerja, dimana sikap kepribadian, motivasi, perilaku,serta pola pikir berdampak terhadap performa organisasi (Hassan et al., 2012).Hasil replikasi penelitian oleh Firdaus (2010) menyatakan dimana peningkatan OCB dapat disebabkan oleh meningkatnya indikator iklim psikologis.

Hasil penelitian Angelina dan Subudi (2014) ditemukan bahwa kepuasan kerja karyawan berpengaruh positif dan signifikan terhadap OCB, hal ini 
mencermikan jika kepuasan kerja karyawan cukup tinggi maka, kesadaran karyawan untuk berkomitmen terhadap kemajuan perusahaan akan meningkat. Secara sederhana perilaku OCB dilakukan oleh para karyawan akanmeningkatkan produktivitas serta dapat melampaui kinerja kompetitor (Sweeney \& McFarlin, 2002).Karyawan ingin membalas rasakenyamanan yang mereka dapatkan dengan perilakuproduktif terhadap organisasinya (Ostroff dalam Robbins, 2001:80).

Tabel 1. Target dan Realisasi Produksi PT. Sarana Tani Pratama Tahun 2016.

\begin{tabular}{cccc}
\hline \multirow{2}{*}{ Bulan } & \multicolumn{3}{c}{ Produk Ikan Sarden } \\
\cline { 2 - 4 } & $\begin{array}{c}\text { Target } \\
\text { (kaleng) }\end{array}$ & $\begin{array}{c}\text { Realisasi } \\
\text { (kaleng) }\end{array}$ & $\begin{array}{c}\text { Target } \\
(\boldsymbol{\%})\end{array}$ \\
\hline Januari & 190.000 & 185.000 & 97,36 \\
Februari & 190.000 & 190.000 & 100 \\
Maret & 200.000 & 210.000 & 105 \\
April & 200.000 & 189.000 & 94,5 \\
Mei & 200.000 & 197.000 & 98,5 \\
Juni & 190.000 & 200.000 & 105,26 \\
Juli & 190.000 & 190.000 & 100 \\
Agustus & 170.000 & 165.000 & 97,05 \\
September & 170.000 & 165.000 & 97,05 \\
Oktober & 190.000 & 200.000 & 105,26 \\
November & 190.000 & 195.000 & 102,63 \\
Desember & 190.000 & 180.000 & 94,73 \\
\hline
\end{tabular}
Sumber: PT. Sarana Tani Pratama, 2017

Berdasarkan Tabel 1diketahui persentase realisasi produksi pada PT. Sarana Tani Pratama menunjukkan tingkat persentase yang berbeda-beda, hal ini dapat disimpulkan jumlah produksi ikan sarden yang dihasilkan belum terealisasikan dengan baik. Peneliti merasa hal tersebut dikarenakan kurangnya kerjasama serta kesadaran dalam tim untuk dapat saling membantu dalam pencapaian target produksi yang stabil. Bertentangan dengan altruism yakni salah satu dimensi dalam OCBdimana memiliki makna mengenaiperilaku memberikan bantuan lain 
tanpa ada paksaan pada tugas-tugas yang berkaitan erat dengan operasional organisasi (Allison et al., 2001).

\section{KAJIAN PUSTAKA DAN HIPOTESIS PENELITIAN}

Teori yang melandasi penelitian ini adalah teori kepuasan kerja yang dikembangkan oleh Federick Herzberg yaitu teori dua faktor (Two factor theory). Dari penelitian yang dilakukan Herzberg ditemukan terdapat dua faktor pendorong yang berkaitan dengan perasaan positif terhadap pekerjaan sehingga mengakibatkan ketidakpuasan kerja.

Kepuasan kerja muncul didasari atas faktor-faktor tertentu. Faktor tersebut bisa berasal dari luar individu yang disebut faktor ekstrinsik dan faktor yang berasal dari dalam individu yang disebut faktor intrinsik. Menurut Mangkunegara (2007: 67) faktor ekstrinsik yang menyebabkan timbulnya rasa tidak puas, yaitu administrasi dan kebijakan perusahaan, kualitas pengawasan, hubungan dengan pengawas, hubungan dengan subordinat, upah, keamanan kerja, kondisi kerja, dan status.

Faktor intrinsik kepuasan kerja diungkapkan oleh Tampubulon (2004: 87) yaitu, faktor intrinsik yang menyebabkan timbulnya rasa puas atau tidak puas, antara lain: prestasi, pengakuan, tanggung jawab, kemajuan, pekerjaan itu sendiri, dan kemungkinan berkembang. Bilamana kedua faktor ini terpenuhi dalam diri individu, maka individu tersebut akan puas dan memunculkan sikap loyal serta menunjukkan kecintaanya terhadap pekerjaan. Namun, apabila faktor-faktor tersebut tidak terpenuhi, maka individu akan merasa tidak puas dan menunjukkan kinerja yang buruk dalam organisasi. 


\section{Iklim Psikologis}

Iklim psikologis menurut pendapat Kahn (1990) (dalam Seniati, 2006) adalah iklim dalam perusahaan yang menyebabkan karyawan secaratulus dan dengan senang hati untuk mencintai pekerjaan mereka ataupun pekerjaan menimbulkanhambatan secara psikologis. Selanjutnya Brown dan Leigh, (1996) menyatakan iklim psikologis mempengaruhi keterlibatan, usaha dan performansiseorang karyawan. Iklim psikologis yang baik dalam sebuah organisasi tentu dapat membuat organisasi dan manajer menunjukkan perilaku OCB mereka yang dilakukan dengan menyertakan karyawan untuk terlibat dalam kegiatan organisasi seperti membantu terwujudnya tujuan dari perusahaan serta membangun hubungan yang bermanfaat bagi rekan kerja dan organisasi (Ribeiro dan Rego, 2009).

Menurut Solomon et al. (1998), iklim psikologis ialah interpretasi perilaku kognitif yang dimiliki individu di sebuah organisasi.Dimensi iklim psikologis menurut Swift dan Campell (1998) yaitu dukungan,otonomi,pengakuan, kohesi inovasi dan tekanan. Sedangkan menurut Brown dan Leigh (1996) terdapat enam dimensi iklim psikologis, yakni dukungan manajemen (supportive management)kejelasan peran (role clarity), ekspresi diri (Self-expression), kontribusi (contribution), pengakuan (recognition,) dan tantangan (challenge).

\section{Kepuasan Kerja}


Kepuasan kerja ialahsikap individumemberikan penggambaran mengenai sikap positif maupun negatif dari tercapainyatugas dalam suatu pekerjaan. Dengan tercapainya apa yang menjadi kebutuhan tersebut akan menciptakan kepuasan tersendiri (Waspodo dan Minadaniati, 2012). Luthans (2006) menjelaskan kepuasan kerja adalah nilai dari kesehatan dan keefektifan organisasi secara keseluruhan. Wibowo (2011) menjelaskan bahwa setiap pekerja mengharapkan mendapatkan rasa kepuasan dari tempat kerja atau perusahaan. Menurut Tranggono dan Kartika (2008) rasa gembira yang dapat dirasakan oleh para karyawan dapat berimbas kepada optimalisasi kinerja organisasi. Jikalau, rasa puas atas pekerjan tersebut sangat dirasakan oleh seluruh karyawan maka seluruh bagian perusahaan akan merasakan kenyamanan dalam mencapai seluruh target pekerjaan demi mencapai tujuan sasaran yang dimiliki oleh perusahaan. Sebaliknya, jikalau para pekerja tidakmerasa puasmaka akan berujung negatifterhadap pekerjaannya(Crossman, danBassem, 2003).

Kepuasan kerja (Rivai \& Sagala, 2009) pada dasarnya sesuatu yang bersifat individual.Diaksa dan Dewi (2014) berpandangan ada baiknya perusahaanmeningkatkankesadaran atas pemberian bonus karyawan didasari dengan keahliansehingga tidak terdapat keluhan yang dapat menurunkankepuasan.Kepuasan kerja menurut Dole dan Schroeder (2001) (dalam Koesmono, 2006), dapat diartikan dengan perasaan dan reaksi individu atau karyawan terhadap lingkungan pekerjaannya. Semakin tinggi peran aspek dalam penyelesaian kerja yang sesuai dengan impian individu, maka semakin tinggi tingkat kepuasan yang dapat dicapai. Menurut Luthans (2006) terdapat dimensi 
kepuasan kerja yang dapat digunakan untuk mengungkapkan karakteristik pekerjaan, dimana orang dapat meresponnya. Dimensi itu adalah dimensi pekerjaan itu sendiri (work it self), dimensiatasan (supervision), dan dimensi rekan kerja (co-workers.),dimensipromosi (promotion)dan dimensigaji/upah (pay).

\section{Organizational Citizenship Behavior (OCB)}

Organizational Citizenship Behavior menurut Robbins \& Judge (2008:40) merupakan perilaku pilihan yang tidak menjadi bagian dari kewajiban kerja formal seorang karyawan, namun mendukung berfungsinya organisasi tersebut secara efektif. Ratnaningsih (2013) menyebutkan OCB merupakan sebuah perilaku positif, yakni perilaku sukarela membantu individu lain dalam penyelesaian suatu pekerjaan. Hal yang sama jugadikemukakan oleh Garay (2006:34)dan Lovell (1999) bahwa OCB merupakan suatu perilaku sukarela yang melebihi dari yang telah disyaratkan oleh organisasi yang tertuang dalam suatu deskripsi pekerjaan yang formal (formal job description).OCB juga dikenal perilaku extra role yang merupakan tindakan ekstra dimanakontribusi yang diberikan melebih peran yang diberikantanpa mengharapkantimbal balik (Yaghoubi et al., 2011).Organizational Citizenship Behavior menurut Aldag dan Resckhe (1997) merupakan kontribusi individu yang melebihi tuntutan peran di tempat kerja. Faktor-faktor yang dapat mempengaruhi OCB yakni kepuasan kerja,suasana hati (mood), iklim organisasi,persepsi terhadap dukungan, kualitas interaksi karyawan dengan atasan, lama kerja, serta jenis kelamin(Andriani dkk., 2012).

Dimensi Organizational Citizenship Behavior (OCB) 
Terdapatlima dimensi dari OCB dikemukakan oleh Organ (1988) (dalam Allison, 2001), yaknialtruismatau. Perilaku, ini bisa diartikan perilaku menolong yang berarti ketersediaan diri untuk menolong rekan kerja dalam penyelesaian pekerjaanpada situasi yang tidak biasa.Kedua, civic virtueyakniadanya dukungan partisipasi secara sukarela secara profesional maupun sosial secara alami.Ketiga, conscientiousness yakni perilaku pemenuhan tugas diatas batas minimal yang dihimbau oleh perusahaan. Keempat, courtesy yakni perilaku membantu pekerjaan rekan maupun atasan demi meringkan permasalahan dan mempersingkat waktu pekerjaan. Kelima, sportmanship yakni melihat suatu pekerjaan maupun kegiatan tanpa memandang hal negatif yang dimiliki dengan menjunjung tinggi jiwa sportivitas.

Penelitian yang dilakukan oleh Biswas dan Varma (2007) menyatakanOrganizational Citizenship Behavior dan juga kepuasan kerja karyawan dipengaruhi secara signfikan oleh iklim psikologis. Parker et al. (2003) menyatakan iklim psikologis berhubungan erat dengan perilaku organisasi karyawan diantaranyakomitmen, kepuasan kerja, keterlibatan, serta motivasi yang dimiliki karyawan. Penelitian yang dilakukan Yekti (2006) pada PT. Cola Cola Bottling di Semarang menyatakan bahwa iklim psikologis berpengaruh positif terhadap kepuasan kerja.Berdasarkanteori dan penelitian empiris dirumuskan hipotesis sebagai berikut :

$\mathrm{H}_{1}$ : Iklim psikologis mempunyai pengaruh positif signifikan terhadap kepuasan kerja

Ribeiro dan Rego (2009) menunjukkan bahwa organisasi dan manajer dapat mempromosikan OCB jika mereka menanamkan iklim psikologis yang baik, 
sehingga dapat disimpulkan iklim psikologis berpengaruh positif terhadap OCB. Penelitian yang dilakukan Eisele dan D'Amato (2011) dalam penelitiannya mengenai peran OCB sebagai mediasi iklim psikologis dengan work performance dan well-being, menyatakan bahwa iklim psikologis mempunyai hubungan positif terhadap OCB.Hasil replikasi penelitian oleh Firdaus (2010) yang menyatakan bahwa iklim psikologis mempunyai pengaruh signifikan terhadap OCB dimana peningkatan OCB dapat disebabkan oleh meningkatnya indikator iklim psikologis. Berdasarkan landasan teori dari beberapa penelitian yang telah disampaikan dapat dirumuskan hipotesis sebagai berikut :

$\mathrm{H}_{2}$ : Iklim psikologis berpengaruh positifsignifikan terhadap OrganizationalCitizenship Behavior

Hasil penelitian Angelina dan Subudi (2014), ditemukan bahwa kepuasan kerja karyawan memiliki pengaruh yang positif serta signifikan terhadap OCB. Fatimah dan Halim (2011) dalam penelitiannya di Selangor Malaysia membuktikan adanya hubungan positif antara variabel kepuasan kerja terhadap OCB. Sementara Leet al. (2013) menemukan hal yang sama pada 30 perusahaan di Korea. Penelitian yang dilakukan oleh Osman et al. (2015) di Amerika dengan melibatkan 300 orang responden OCB dipengaruhi secara positif signifikan oleh variabel kepuasan kerja. Penelitian Lu, C. et al. (2013) yang melibatkan 150 karyawan sebagai responden juga menunjukkan hasil studi yang serupa.Berdasarkan landasan teori dan beberapa penelitian empiris tersebut maka dapat dirumuskan hipotesis sebagai berikut :

$\mathrm{H}_{3}$ : Kepuasan Kerja berpengaruh positif dan signifikan terhadap OrganizationalCitizenship Behavior 
Gambar konseptual dalam penelitian bertujuan untuk memberikan gambaran dan asumsi terhadap variabel-variabel yang akan diteliti. Berikut adalah gambar konseptual dan hubungan dari masing-masing variabel yang digunakan pada penelitian :

\section{Gambar 1. Model Konseptual (Conceptual Framework)}

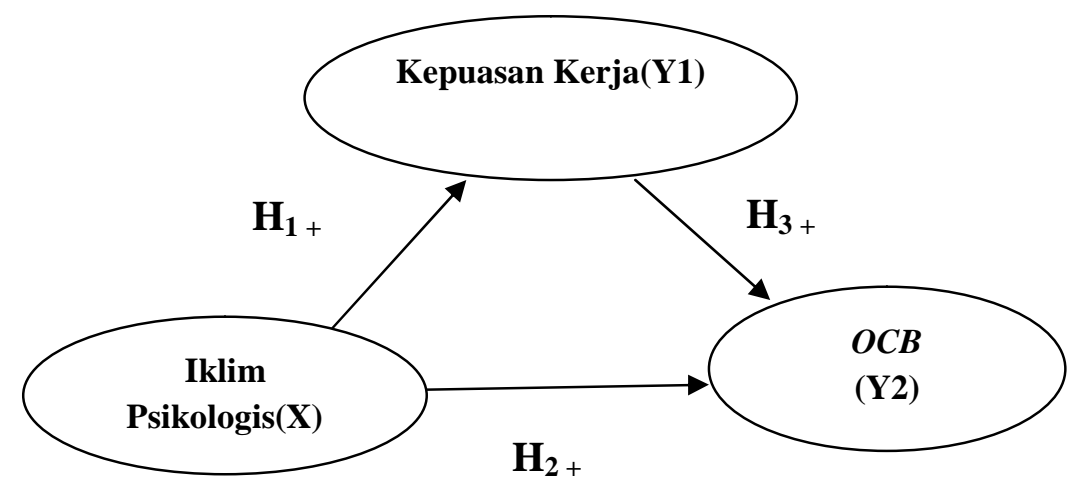

\section{METODE PENELITIAN}

Pendekatan yang dipilihyakni pendekatan secara kuantitatif yang berbentuk secara asosiatif. Lokasi penelitian dilakukan pada PT. Sarana Tani Pratama yang beralamat di Desa Pengambengan, Negara Bali. Alasan peneliti melakukan penelitian di PT. Sarana Tani Pratama yaitu karena perusahaan ini bekerja secara tim untuk dapat mencapai target produksi, sehingga banyak timbul permasalahan yang berkaitan dengan judul penelitian. Objek penelitian yaitu, iklim psikologis, kepuasan kerja, dan OCB.Populasi dalam penelitian ini adalah 131 yaitu jumlah seluruh karyawan di PT. Sarana Tani Pratama.Teknik sampling dalam penelitian yakni dengan teknik probability sampling. Penentuan ukuran sampel pada penelitian ini menggunakan rumus Slovin (Umar, 2008:78) 
Untuk memperoleh data yang dibutuhkan dalam penelitian ini, akan dilakukan dengan metode pengumpulan data sebagai berikut :

$$
n=\frac{N}{1+N^{2}}
$$

Keterangan:

$$
\begin{array}{ll}
\mathrm{n} & =\text { Jumlah sampel } \\
\mathrm{N} & =\text { Jumlah populasi } \\
\mathrm{e} & =\text { Toleransi kesalahan sebesar } 0.05
\end{array}
$$

$$
n=\frac{131}{1+(131)\left(0,05^{2}\right)}=98,68
$$

$\mathrm{n}=98,68$ menjadi 99 dikarenakan subjek adalah orang.

Hasil tersebut, jumlah sebanyak 99orang. Proporsi pengambilan sampel dengan proportional random sampling. Tabel 2 memperlihatkan populasi dan sampel karyawan di PT Sarana Tani Pratama.

Tabel 2.

Populasi dan Sampel PT Sarana Tani Pratama

\begin{tabular}{cccc}
\hline No & Bagian & Populasi & Sampel \\
\hline 1 & Human Resource & 3 & 2 \\
2 & Kabag. Pengadaan & 5 & 4 \\
3 & Kabag. Gudang & 4 & 3 \\
4 & Engineering & 10 & 8 \\
5 & Administration & 5 & 4 \\
6 & Kabag. Quality Assurance & 4 & 3 \\
7 & Production & 100 & 76 \\
Total & & 131 & 99 \\
\hline Sumber $:$ PT. Sarana Tani Pratama, 2017 & &
\end{tabular}

Metode pengumpulan data dengan teknik observasi, wawancara dan penyebaran kuisioner. Metode pengukuran data menggunakan skala yaitu skala Likert.Dalam peneletian ini pengujian intrumen dengan dilakukan dengan uji validitas dan uji reabilitas. Teknik analisis data yang digunakan dalam penelitian 
ini yakni uji asumsi klasik dan teknik analisis jalur atau path analysis dengan bantuan aplikasi IBM SPSS.

\section{HASIL DAN PEMBAHASAN}

Jumlah responden dominan berjenis kelamin laki-laki sebanyak 72 orang dengan persentase 72,7 sedangkan berjenis kelamin perempuan sebanyak 27 orang dengan persentase 27,3. Mayoritas responden di PT. Sarana Tani Pratama berusia 20-29 tahun sebanyak 52 orang dengan persentase 52,6 persen. Faktor usia dapat menunjang kegiatan organisasi dalam menghasilkan jasa yang berkualitas, karena dengan umur produktif yang dimiliki oleh karyawan akan berkorelasi di dalam mencapai tujuan organisasi.

Tingkat pendidikan karyawan yang bekerja di PT. Sarana Tani Pratama dominan berpendidikan SMA/SMK yaitu sebanyak 70 orang dengan persentase sebesar 70,8\% .Pendidikan S1 sebanyak 18 dengan persentase 18,2\%, D3 sebanyak 2 orang dengan persentase $2 \%$, D2 sebanyak 3 orang dengan persentase 3\% D1 sebanyak 6 orang dengan persentase $6 \%$. Tingkat pendidikan merupakan salah satu indikasi kualitas SDM.

Masa kerja karyawan di PT. Sarana Tani Pratama dominan memiliki pengalaman kerja pada rentan waktu 1 sampai 9 tahun dengan jumlah karyawan sebanyak 52 orang dengan persentase 52,6 persen. Masa kerja merupakan periode waktu yang dilalui oleh karyawan dalam bekerja.

\section{Uji Validitas}

Hasil penelitian yang valid adalah bila terdapat kesamaan antara data yang terkumpul dengan data yang sesunguhnya terjadi pada objek yang diteliti. Uji 
E-Jurnal Manajemen, Vol. 8, No. 1, 2019: 7253 - 7282

validitas dilakukan untuk setiap butir pertanyaan dan tabel berikut ini menunjukkan hasilnya.

Tabel 4.2

Hasil Uji Validitas

\begin{tabular}{|c|c|c|c|c|}
\hline No. & Variabel & $\begin{array}{c}\text { Item } \\
\text { Pernyataan }\end{array}$ & $\begin{array}{l}\text { Korelasi Item } \\
\text { Total }\end{array}$ & Keterann \\
\hline \multirow{17}{*}{1} & \multirow{17}{*}{ Iklim Psikologis $\left(\mathrm{X}_{1}\right)$} & $\mathrm{X}_{1.1}$ & 0,855 & Valid \\
\hline & & $\mathrm{X}_{1.2}$ & 0,937 & Valid \\
\hline & & $\mathrm{X}_{1.3}$ & 0,926 & Valid \\
\hline & & $\mathrm{X}_{1.4}$ & 0,879 & Valid \\
\hline & & $\mathrm{X}_{1.5}$ & 0,926 & Valid \\
\hline & & $\mathrm{X}_{1.6}$ & 0,871 & Valid \\
\hline & & $\mathrm{X}_{1.7}$ & 0,931 & Valid \\
\hline & & $\mathrm{X}_{1.8}$ & 0,903 & Valid \\
\hline & & $\mathrm{X}_{1.9}$ & 0,859 & Valid \\
\hline & & $X_{1.10}$ & 0,823 & Valid \\
\hline & & $X_{1.11}$ & 0,850 & Valid \\
\hline & & $\mathrm{X}_{1.12}$ & 0,913 & Valid \\
\hline & & $\mathrm{X}_{1.13}$ & 0,893 & Valid \\
\hline & & $\mathrm{X}_{1.14}$ & 0,894 & Valid \\
\hline & & $X_{1.15}$ & 0,908 & Valid \\
\hline & & $\mathrm{X}_{1.16}$ & 0,939 & Valid \\
\hline & & $X_{1.17}$ & 0,903 & Valid \\
\hline \multirow{5}{*}{2} & \multirow{5}{*}{ Kepuasan Kerja $\left(\mathrm{Y}_{1}\right)$} & $\mathrm{Y}_{11}$ & 0,954 & Valid \\
\hline & & $\mathrm{Y}_{1.2}$ & 0,881 & Valid \\
\hline & & $\mathrm{Y}_{1.3}$ & 0,915 & Valid \\
\hline & & $\mathrm{Y}_{1.4}$ & 0,887 & Valid \\
\hline & & $\mathrm{Y}_{15}$ & 0,943 & Valid \\
\hline \multirow{5}{*}{3} & \multirow{5}{*}{$\begin{array}{c}\text { Organizational } \\
\text { Citizenship Behavior (Y2) }\end{array}$} & $Y_{2.1}$ & 0,868 & Valid \\
\hline & & $\mathrm{Y}_{2.2}$ & 0,954 & Valid \\
\hline & & $\mathrm{Y}_{2.3}$ & 0,849 & Valid \\
\hline & & $\mathrm{Y}_{2.4}$ & 0,934 & Valid \\
\hline & & $\mathrm{Y}_{2.5}$ & 0,934 & Valid \\
\hline
\end{tabular}

Sumber: Hasil olahan data penelitian, 2017

Tabel 4 menunjukkan bahwa seluruh indikator pernyataan dalam variabel iklim psikologis, kepuasan kerja dan OCBmemiliki korelasi total (pearson correlation) lebih dari 0,30 sehinggamemenuhi syarat data yang valid.

\section{Uji Reliabilitas}


Tabel 5.

Hasil Uji Reliabilitas

\begin{tabular}{lcc}
\hline \multicolumn{1}{c}{ Variabel } & Cronbach'sAlpha & Keterangan \\
\hline Iklim Psikologis (X) & 0,984 & Reliabel \\
Kepuasan Kerja (Y1) & 0,952 & Reliabel \\
Organizational Citizenship Behavior (Y2) & 0,946 & Reliabel \\
\hline Sumber: Hasil olahan data penelitian, 2017 & &
\end{tabular}

Tabel 5 melaporkan ketiga instrumen studi yakni iklim psikologis, kepuasan kerja dan OCBmemiliki koefisien Cronbach's Alpha lebihtinggi dari 0,70. Dapat disimpulkan semua instrumen reliabel sehingga dapat digunakan untuk melakukan penelitian.

\section{Deskripsi Variabel Penelitian}

\section{Iklim Psikologis}

Tabel 6 menunjukkan variabel iklim psikologis diukur dengan menggunakan 17 item pernyataan yang berhubungan dengan iklimpsikologis di perusahaan yang dirasakan oleh karyawan

Tabel 6.

Deskripsi Jawaban Responden Variabel Iklim Psikologis

\begin{tabular}{|c|c|c|c|c|c|c|c|c|}
\hline \multirow{2}{*}{ No. } & \multirow{2}{*}{ Pernyataan } & \multicolumn{5}{|c|}{ Proporsi Jawaban Responden } & \multirow{2}{*}{$\begin{array}{l}\text { Rata } \\
\text {-rata }\end{array}$} & \multirow{2}{*}{ Kriteria } \\
\hline & & STS & TS & $\mathrm{N}$ & $\mathrm{S}$ & SS & & \\
\hline \multicolumn{9}{|c|}{ Dukungan } \\
\hline 1 & $\begin{array}{l}\text { Atasan saya memberi } \\
\text { kesempatan pada } \\
\text { karyawan untuk belajar } \\
\text { dari kesalahan }\end{array}$ & 0 & 11 & 17 & 24 & 47 & 4,08 & Baik \\
\hline 2 & $\begin{array}{l}\text { Atasan saya membantu } \\
\text { pekerjaan karyawan ketika } \\
\text { dibutuhkan }\end{array}$ & 0 & 15 & 10 & 28 & 46 & 4,06 & Baik \\
\hline 3 & $\begin{array}{l}\text { Atasan saya orang yang } \\
\text { dapat diandalkan }\end{array}$ & 0 & 14 & 13 & 17 & 55 & 4,14 & Baik \\
\hline \multicolumn{9}{|c|}{ Otonomi } \\
\hline 1 & $\begin{array}{l}\text { Saya dapat mengorganisir } \\
\text { pekerjaan menurut standar } \\
\text { kinerja saya sendiri }\end{array}$ & 0 & 15 & 11 & 23 & 50 & 4,09 & Baik \\
\hline 2 & $\begin{array}{l}\text { Saya menyelesaikan } \\
\text { pekerjaan dengan cara }\end{array}$ & 0 & 14 & 15 & 24 & 46 & 4,03 & Baik \\
\hline
\end{tabular}


E-Jurnal Manajemen, Vol. 8, No. 1, 2019: 7253 - 7282

\begin{tabular}{|c|l|c|c|c|c|c|c|c|}
\hline & $\begin{array}{l}\text { Sendiri tetapi tetap } \\
\text { mengacu job desk }\end{array}$ & & & & & & & \\
\hline 3 & $\begin{array}{l}\text { Saya dapat menentukan } \\
\text { jadwal untuk kegiatan } \\
\text { kerja saya sendiri }\end{array}$ & 0 & 15 & 11 & 21 & 52 & 4,11 & Baik \\
\hline
\end{tabular}

\begin{tabular}{|c|c|c|c|c|c|c|c|c|}
\hline \multirow{2}{*}{ No. } & \multirow{2}{*}{ Pernyataan } & \multicolumn{5}{|c|}{ Proporsi Jawaban Responden } & \multirow{2}{*}{$\begin{array}{l}\text { Rata } \\
\text {-rata }\end{array}$} & \multirow{2}{*}{ Kriteria } \\
\hline & & STS & $\mathrm{TS}$ & $\mathrm{N}$ & $\mathrm{S}$ & SS & & \\
\hline \multicolumn{9}{|c|}{ Pengakuan } \\
\hline 1 & $\begin{array}{l}\text { Atasan saya tidak } \\
\text { bertindak pilih kasih } \\
\text { terhadap sesama karyawan }\end{array}$ & 0 & 18 & 11 & 19 & 51 & 4,04 & Baik \\
\hline 2 & $\begin{array}{l}\text { Atasan saya mengapresiasi } \\
\text { kemajuan yang saya capai } \\
\text { di perusahaan ini }\end{array}$ & 0 & 14 & 14 & 14 & 57 & 4,15 & Baik \\
\hline 3 & $\begin{array}{l}\text { Atasan saya memberikan } \\
\text { pengakuan terhadap setiap } \\
\text { kinerja karyawan yang } \\
\text { baik }\end{array}$ & 0 & 16 & 14 & 21 & 48 & 4,02 & Baik \\
\hline \multicolumn{9}{|c|}{ Kohesi } \\
\hline 1 & $\begin{array}{l}\text { Dalam perusahaan ini } \\
\text { terdapat semangat tim } \\
\text { dalam melakukan } \\
\text { pekerjaan }\end{array}$ & 0 & 10 & 16 & 28 & 45 & 4,09 & Baik \\
\hline 2 & $\begin{array}{l}\text { Dalam perusahaan ini } \\
\text { karyawan saling } \\
\text { memperhatikan } \\
\text { kepentingan satu sama } \\
\text { lain. }\end{array}$ & 0 & 13 & 15 & 18 & 53 & 4,12 & Baik \\
\hline 3 & $\begin{array}{l}\text { Karyawan cenderung } \\
\text { dapat berkomunikasi } \\
\text { dengan baik kepada } \\
\text { karyawan lainnya } \\
\text { perusahaan ini. }\end{array}$ & 0 & 14 & 14 & 28 & 43 & 4,01 & Baik \\
\hline \multicolumn{9}{|c|}{ Inovasi } \\
\hline 1 & $\begin{array}{l}\text { Atasan saya meminta } \\
\text { pendapat dari karyawan } \\
\text { tentang evaluasi kinerja } \\
\text { perusahaan }\end{array}$ & 0 & 18 & 9 & 26 & 46 & 4,01 & Baik \\
\hline
\end{tabular}


I Gede Indra Tenaya, Pengaruh Iklim Psikologis ....

\begin{tabular}{|c|l|c|c|c|c|c|c|c|}
\hline 2 & $\begin{array}{l}\text { Atasan saya menemukan } \\
\text { inovasi baru dalam } \\
\text { menyelesaikan masalah } \\
\text { pekerjaan }\end{array}$ & 0 & 16 & 15 & 20 & 48 & 4,01 & Baik \\
\hline 3 & $\begin{array}{l}\text { Atasan membantu } \\
\text { karyawan untuk } \\
\text { mengembangkan gagasan- } \\
\text { gagasan baru }\end{array}$ & 0 & 17 & 8 & 23 & 51 & 4,09 & Baik \\
\hline
\end{tabular}

\begin{tabular}{|c|l|c|c|c|c|c|c|c|c|}
\hline \multirow{2}{*}{ No. } & Pernyataan & \multicolumn{6}{|c|}{ Proporsi Jawaban Responden } & $\begin{array}{c}\text { Rata } \\
\text {-rata }\end{array}$ & Kriteria \\
\cline { 2 - 7 } & STS & TS & N & S & SS & \\
\hline 1 & $\begin{array}{l}\text { Saya merananatertekan } \\
\text { ketika pekerjaan } \\
\text { dievaluasi }\end{array}$ & 0 & 16 & 14 & 13 & 56 & 4,10 & Baik \\
\hline 2 & $\begin{array}{l}\text { Saya merasa tertekan jika } \\
\text { mengerjakan pekerjaan } \\
\text { dengan tergesa-gesa. }\end{array}$ & 0 & 19 & 7 & 19 & 54 & 4,09 & Baik \\
\hline \multicolumn{7}{|c|}{ Rata-rata } & 4,07 & Baik \\
\hline
\end{tabular}

Sumber : Hasil olahan data penelitian, 2017

Tabel 6secara keseluruhan memiliki nilai rata-rata 4,07 dimana nilai terendah sebesar 4,01 dan yang tertinggi sebesar 4.15. Hal ini memiliki arti bahwa iklim psikologis yang ada di PT. Sarana Tani Pratama termasuk dalam kriteria baik.

\section{Kepuasan Kerja}

Tabel 7.

Deskripsi Jawaban Responden Variabel Kepuasan Kerja

\begin{tabular}{|c|c|c|c|c|c|c|c|c|}
\hline \multirow{2}{*}{ No } & \multirow{2}{*}{ Pernyataan } & \multicolumn{5}{|c|}{$\begin{array}{l}\text { Proporsi Jawaban } \\
\text { Responden }\end{array}$} & \multirow{2}{*}{$\begin{array}{l}\text { Rata- } \\
\text { rata }\end{array}$} & \multirow[t]{2}{*}{ Kriteria } \\
\hline & & STS & TS & $\mathbf{N}$ & $\mathbf{S}$ & SS & & \\
\hline 1 & $\begin{array}{l}\text { Pekerjaan saya sekarang } \\
\text { memberikan saya } \\
\text { kesempatan untuk belajar. }\end{array}$ & 0 & 17 & 11 & 15 & 56 & 4,11 & Baik \\
\hline 2 & $\begin{array}{l}\text { Pekerjaan saya sekarang } \\
\text { sesuai dengan keahlian saya. }\end{array}$ & 0 & 15 & 15 & 11 & 58 & 4,13 & Baik \\
\hline 3 & $\begin{array}{l}\text { Besarnya gaji yang saya } \\
\text { terima sesuai dengan }\end{array}$ & 0 & 14 & 17 & 25 & 43 & 3,97 & Baik \\
\hline
\end{tabular}




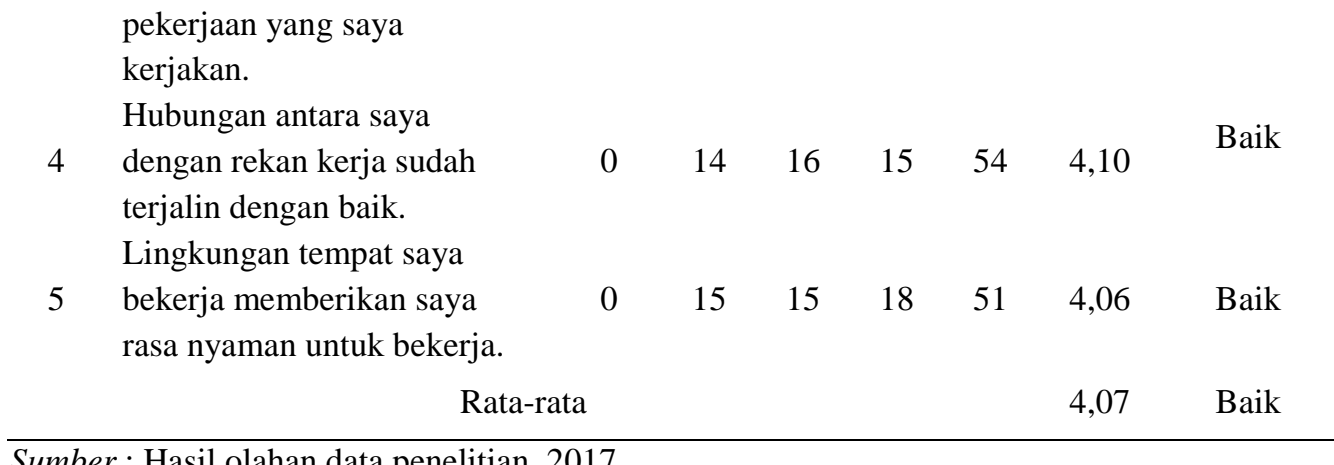

Tabel 7secara keseluruhan memiliki nilai rata-rata 4,07 dimana nilai terendah sebesar 3,97 dan yang tertinggi sebesar 4.13. Hal ini memiliki arti bahwa kepuasan kerja karyawan yang ada di PT. Sarana Tani Pratama termasuk dalam kriteria baik.

\section{Organizational Citizenship Behavior}

Tabel 8 menunjukkan variabel Organizational Citizenship Behavior yang diperhitungkan dengan penggunaan 5pernyataan yang memiliki hubungan dengan Organizational Citizenship Behaviorkaryawan dengan pekerjaannya di perusahaan.

\section{Tabel 8.}

Deskripsi Jawaban Responden Variabel Organizational Citizenship Behavior

\begin{tabular}{|c|c|c|c|c|c|c|c|c|}
\hline \multirow{2}{*}{ No } & \multirow{2}{*}{ Pernyataan } & \multicolumn{5}{|c|}{$\begin{array}{c}\text { Proporsi Jawaban } \\
\text { Responden }\end{array}$} & \multirow{2}{*}{$\begin{array}{l}\text { Rata- } \\
\text { rata }\end{array}$} & \multirow[t]{2}{*}{ Kriteria } \\
\hline & & STS & TS & $\mathbf{N}$ & $\mathbf{S}$ & SS & & \\
\hline 1 & $\begin{array}{l}\text { Saya membantu rekan kerja } \\
\text { yang beban kerjanya } \\
\text { berlebihan. }\end{array}$ & 0 & 16 & 13 & 19 & 51 & 4,06 & Baik \\
\hline 2 & $\begin{array}{l}\text { Saya mau melakukan } \\
\text { pekerjaan lebih walaupun } \\
\text { tidak ada yang meminta. }\end{array}$ & 0 & 15 & 11 & 22 & 51 & 4,10 & Baik \\
\hline 3 & $\begin{array}{l}\text { Saya sangat menghargai } \\
\text { sesama rekan kerja apa pun } \\
\text { jabatannya. }\end{array}$ & 0 & 16 & 14 & 12 & 57 & 4,11 & Baik \\
\hline 4 & $\begin{array}{l}\text { Saya selalu menerima } \\
\text { kebijakan yang berlaku di } \\
\text { tempat saya bekerja. }\end{array}$ & 0 & 16 & 13 & 17 & 53 & 4,08 & Baik \\
\hline 5 & Saya selalu berpartisipasi & 0 & 16 & 15 & 20 & 48 & 4,01 & Baik \\
\hline
\end{tabular}


dalam berbagai kegiatan di

tempat saya bekerja

\begin{tabular}{rrr} 
Rata-rata & 4,07 & Baik \\
\hline Sumber $:$ Hasil olahan data penelitian, 2017 &
\end{tabular}

Tabel 8secara keseluruhan memiliki nilai rata-rata 4,07 dimana nilai terendah sebesar 4,01 dan yang tertinggi sebesar 4.11. Hal ini memiliki arti bahwa perilaku OCB karyawan yang ada di PT. Sarana Tani Pratama termasuk dalam tergolong baik.

\section{Path Analysis (Analisis Jalur)}

Analisis jalur (path analysis) digunakan guna menguji hipotesis secara pengaruh langsung dan tidak langsung iklim psikologis, kepuasan kerja dan organizational citizenship behavior. Sebelum dilakukannya analisis, seluruh model telah melewati uji asumsi klasik yaitu uji normalitas, uji multikolinearitas dan uji heterokedastisitas serta hasil menunjukkan seluruh model tidak terdapat gejala- gejala asumsi klasik. Penyelesaian analisis jalur tersebut dibagi menjadi dua model yaitu model pertama pengaruh iklim psikologis terhadap kepuasan kerja dan model kedua adalah pengaruh iklim psikologis dan kepuasan kerja terhadap organizational citizenship behavior.

\section{Merumuskan Hipotesis dan Persamaan Struktural}

\section{Model I}

Hipotesis : Iklim Psikologis berpengaruh positifsignifikan terhadap

$$
\text { Kepuasan Kerja }
$$

Struktur $\quad: Y_{1}=\rho y_{1} x X+\varepsilon_{1}$

Kepuasan kerja $Y_{1}=0,848$ iklim psikologis $+0,53$

Keterangan : $Y_{1} \quad=$ kepuasan kerja 


$$
\begin{aligned}
\mathrm{X}_{1} & =\text { iklim psikologis } \\
& =\sqrt{1}-k^{2}=\sqrt{1}-0,719=0,53
\end{aligned}
$$

$\mathrm{R}$ square yang dihasilkan model I adalah 0,719 memiliki arti pengaruh iklim psikologis terhadap kepuasan kerja yakni 71,9\% sedangkan sisanya dipengaruhi oleh faktor lain.

\section{Model II}

Hipotesis : iklim psikologis dan kepuasan kerja berpengaruh terhadap organizational citizenship behavior

Struktur $\quad: Y_{2}=\rho y_{2} x X+\rho y_{2} y_{1} Y_{1}+\varepsilon_{2}$

OCB $Y_{2}=0,303$ iklim psikologis $+0,669$ kepuasan kerja $+0,34$

Keterangan : $Y_{2}=$ organizational citizenship behavior $(O C B)$

$$
\begin{gathered}
\mathrm{X}_{1} \quad=\text { Iklim Psikologis } \\
Y_{1} \quad=\text { Kepuasan Kerja } \\
2=\sqrt{1}-R^{2}=\sqrt{1}-0,884=0,34
\end{gathered}
$$

Nilai R square padamodel II adalah 0,884 , artinya pengaruh iklim psikologis dan kepuasan kerja terhadap organizational citizenship behavior sebesar $88,4 \%$ sedangkan sisanya dipengaruhi oleh faktor lain.

\section{Menggambar Diagram Jalur Lengkap}

Pengaruh langsung masing masing variabel dapat dilihat pada gambar 2.

\section{Gambar 2. Diagram jalur lengkap}

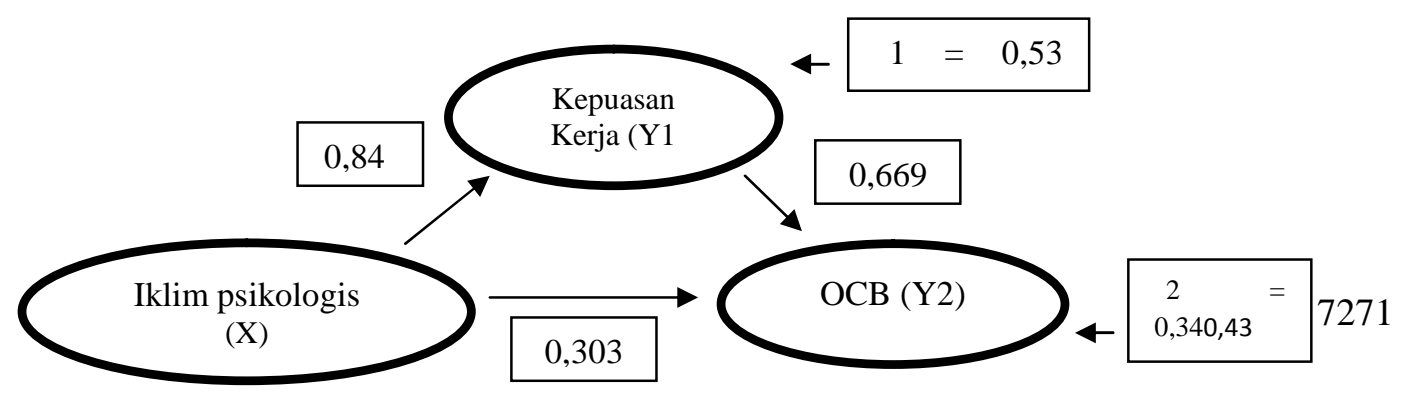


Gambar 2 dapat dilihat pengaruh langsung masing masing variabel yakni pengaruh iklim psikologis terhadap kepuasan kerja dengan nilai standardized coefficients beta yaitu 0,848 yang dimana mengindikasikan arah positif. Berarti dapat disimpulkan bahwa iklim psikologis memiliki pengaruh posiif terhadap kepuasan kerja.

Pengaruh iklim psikologis terhadap organizational citizenship behaviordengan nilai standardized coefficients beta yaitu 0,303 yang dimana mengindikasikan arah positif. Dapat disimpulkan organizational citizenship behavior dipengaruhi positif oleh iklim organisasi.

OCB yang dipengaruhi oleh kepuasan kerja yang ditunjukkandengan nilai standardized coefficients beta yaitu 0,669 yang dimana mengindikasikan arah positif. Berarti kepuasan kerja memiliki pengaruh secara positif terhadap organizational citizenship behavior.

\section{Koefisien Jalur Simultan dan Parsial}

\section{Model I}

Tabel 9.

Rekapitulasi Output Model I

\begin{tabular}{|c|c|c|c|c|c|c|}
\hline \multicolumn{7}{|c|}{ Coefficients $^{\mathrm{a}}$} \\
\hline \multirow{2}{*}{\multicolumn{2}{|c|}{ Model }} & \multicolumn{2}{|c|}{ Unstandardized Coefficients } & $\begin{array}{l}\text { Standardized } \\
\text { Coefficients }\end{array}$ & \multirow[b]{2}{*}{$\mathrm{T}$} & \multirow[b]{2}{*}{ Sig. } \\
\hline & & $\mathrm{B}$ & Std. Error & Beta & & \\
\hline \multirow[t]{2}{*}{1} & (Constant) & 1,537 &, 838 & & 1,835 &, 070 \\
\hline & $\begin{array}{l}\text { Iklim } \\
\text { psikologis }\end{array}$ &, 259 &, 016 &, 848 & 15,763 &, 000 \\
\hline \multicolumn{4}{|c|}{$\begin{array}{l}\text { R Square }=0,719 \\
\text { Adj R Square }=0,716 \\
\text { a. Dependent Variable: kepuasan kerja }\end{array}$} & \multicolumn{3}{|c|}{$\begin{array}{l}\text { F hitung }=248,465 \\
\text { Probabilitas } / \text { sig }=0,000\end{array}$} \\
\hline
\end{tabular}


Sumber : Hasil olahan data penelitian, 2017

Nilai dari sig.t sebesar 0,000 memiliki nilai lebih rendah dibandingkan sig. yang digunakan $(0,000 \leq 0,05)$ menunjukkan pengaruh yang signifikan. Nilai beta pada kolom standardized coefficientsialah 0,848 memiliki indikasi arah yang positif. Disimpulkan bahwa iklim psikologis terhadap kepuasan kerja memiliki pengaruh positif sertaH $\mathrm{H}_{1}$ dapat diterima.

\section{Model II}

\section{Tabel 10.}

Rekapitulasi Output Model II Coefficients $^{\mathrm{a}}$

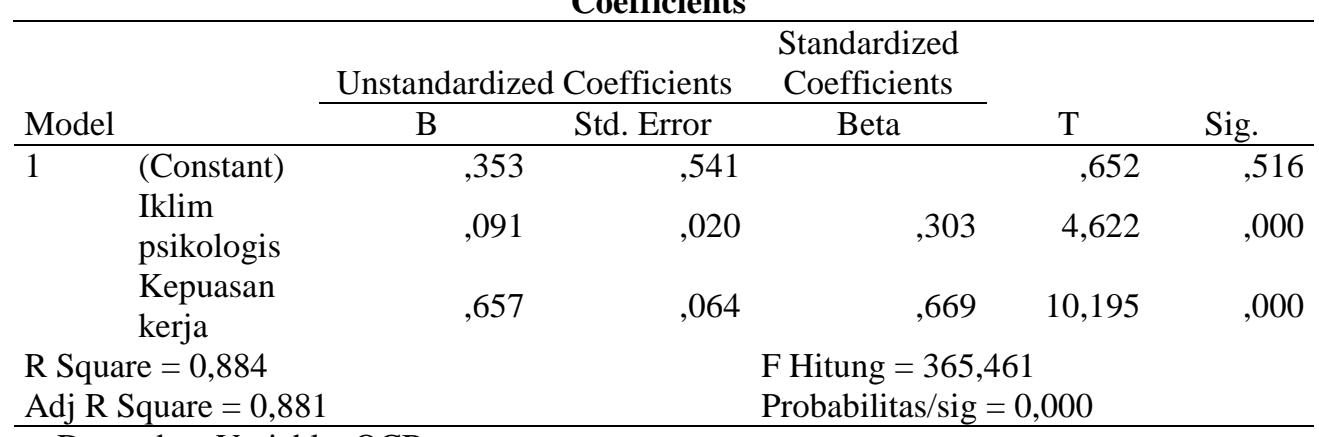

a. Dependent Variable: OCB

Sumber: Hasil olahan data penelitian, 2017

Nilai sig. F sebesar 0,000 lebih rendah dibanding nilai sig. $(0,000<0,05)$ menginformasikan bahwa iklim psikologis dan kepuasan kerja berpengaruh simultan terhadap organizational citizenship behavior. Perbandingan nilai sig.t sebesar 0,000 lebih rendah dibanding nilai sig. yang dipergunakan 0,05, ini memiliki artipengaruhnya secara signifikan. Nilai beta di kolomstandardized coefficientsyakni 0,303 menginformasikan arah positif. Kesimpulannyaiklim psikologis memiliki pengaruh positif signifikan terhadap organizational citizenship behavior yang berarti $\mathrm{H}_{2}$ diterima

Hasil perhitungan didapatkannilai sig.t 0,000 lebih rendah dibandingkan nilai sig. yang digunakan $(0,000 \leq 0,05)$, menginformasikan terdapat pengaruh 
yang signifikan. Nilai koefisien beta pada kolomstandardized coefficientsyakni 0,669 menginformasikan arah yang positif. Memiliki arti kepuasan kerja mempengaruhi OCB secara positif dan signifikan yang berartiH ${ }_{3}$ diterima.

Tabel 11.

Pengaruh Langsung, Pengaruh Tidak Langsung dan Pengaruh Total

\begin{tabular}{lccc}
\hline \multicolumn{1}{c}{ Pengaruh Variabel } & $\begin{array}{c}\text { Pengaruh } \\
\text { Langsung }\end{array}$ & $\begin{array}{c}\text { Pengaruh Tidak Langsung } \\
\text { (Melalui Kepuasan kerja) }\end{array}$ & $\begin{array}{c}\text { Pengaruh } \\
\text { Total }\end{array}$ \\
\hline $\begin{array}{l}\text { Iklim psikologis ke } \\
\text { kepuasan kerja }\end{array}$ & 0,848 & - & 0,848 \\
$\begin{array}{l}\text { Iklim psikologis ke } \\
\text { OCB }\end{array}$ & 0,303 & 0,567 & 0,87 \\
$\begin{array}{l}\text { Kepuasan kerja ke } \\
\text { OCB }\end{array}$ & 0,669 & - & 0,669 \\
\hline Sumber: Hasil olahan data penelitian, 2017 & & \\
\end{tabular}

Sumber: Hasil olahan data penelitian, 2017

Hasil tabel 11 menunjukkan bahwa iklim psikologis dapat berpengaruh langsung ke organizational citizenship behaviordan dapat juga berpengaruh tidak langsung dari iklim psikologis ke kepuasan kerja lalu ke organizational citizenship behavior

$$
\begin{array}{ll}
\text { Pengaruh Langsung } & =0.303 \\
\text { Pengaruh Tidak Langsung } & =(0,848 \times 669)=0,567 \\
\text { Total pengaruh } & =0,303+0,567=0,87
\end{array}
$$

Kesimpulannya, pengaruh tidak langsung sebesar 0,567 lebih besar dari pengaruh langsung 0,303, yang berarti kepuasan kerja mampu memediasi pengaruh iklim psikologis terhadap organizational citizenship behavior.

\section{Pemeriksaan Validitas Model}


Memeriksa validitas model pada studi dilakukan dengan memperhitungkan nilaitotal koefisien determinan.

$$
\begin{aligned}
K^{2} I l & =1-\left(\mathrm{Pe}_{1}\right)^{2}\left(\mathrm{Pe}_{2}\right)^{2} \\
& =1-(0,53)^{2}(0,34)^{2} \\
& =0,967
\end{aligned}
$$

Jumlah yang didapatkan, menginformasikan model penelitian dapat menjelaskan $96,7 \%$ variasi dan sisanya sebesar 3,3\% dipengaruhi oleh variabel yang tidak terdapat dalam model.

\section{Pembahasan Hasil Penelitian}

\section{Pengaruh Iklim Psikologis terhadap Kepuasan Kerja}

Hipotesis pertama menyatakan bahwa iklim psikologis memiliki pengaruh positif dan signifikan terhadap kepuasan kerja. Artinya iklim psikologis yang baik akan meningkatkan tingkat kepuasan kerja keluar karyawan di perusahaan. Semakin baik tdan kondusifnya iklim psikologis di perusaaan maka para karyawannya akan semakin puas terhadap pekerjaan maupun perusahaannya. Hasilsesuai dengan penelitian-penelitian empiris sebelumnya yang menyatakan kepuasan kerja dipengaruhi secarapositif dan signifikan oleh kepuasan kerja (Yekti, 2006). Dan iklim psikologis berpengaruh positif terhadap OCB dan kepuasan kerja menurut penelitian yang dilakukan Biswas dan Varma (2007). Hal sama juga diperoleh Parker et al. (2003) yang menemukan bahwa iklim psikologis memilikiketerkaitanyang erat dengan tingkah laku serta perilakukaryawan dalam organisasi.

Pengaruh Iklim Psikologis terhadap Organizational Citizenship Behavior. 
Hipotesis kedua menyatakan bahwa iklim psikologis memiliki pengaruh positif dan signifikan terhadap organizational citizenship behavior. Hal ini dalam artian semakin baik terciptanya iklim psikologis di perusahaan, maka akan memunculkan perilaku extra role atau organizational citizenship behaviordari karyawan yang akan membuat kinerja perushaan semakin baik.Hasil penelitian ini sesuai dengan hasil studi yang dilakukan Ribeiro dan Rego, 2009. Hasil sama juga ditemukan pada penelitian yang dilakukan Eisele dan D'Amato (2011) mengenai peran OCB sebagai mediasi iklim psikologis dengan work performance dan wellbeing yang menyatakan iklim psikologis mempunyai hubungan positif dengan OCB. Selanjutnya penelitian Firdaus (2010) yang juga menyatakan iklim psikologis mempunyai pengaruh positif signifikan terhadap organizational citizenship behaviordimana peningkatan OCB di perusahaan disebabkan oleh meningkatnya indikator iklim psikologis.

\section{Pengaruh Kepuasan Kerja terhadap Organizational Citizenship Behavior.}

Hipotesis ketiga menyatakan bahwa kepuasan kerja memiliki pengaruh positif dan signifikan terhadap organizational citizenship behavior. Dimana ini berarti bahwa semakin tinggi kepuasan kerja selama bekerja akan terciptakesadaran karyawan di perusahaan untuk melakukan perilaku extra role (OCB). Hasil penelitian ini sesuai menurut Angelina dan Subudi (2014) dimana kepuasan kerja pada karyawan berpengaruh terhadap organizational citizenship behaviordi perusahaan.Jika karyawan tidak puas dengan pekerjaan mereka, mereka cenderung untuk melakukan pekerjaan individu tanpa menghiraukan kinerja dari rekan maupun kinerja perushaan itu sendiri. Begitu juga sebaliknya 
jika karyawan puas dengan pekerjaan mereka, maka otomatis akan timbul perilaku untuk lebih giat dalam membantu rekan lain dan terciptanya teamwork dalam perusahaan. Penelitian lainnya juga mengatakan bahwa kepuasan kerjaberpengaruh terhadap perilaku OCB di dalam organisasi (Osman et al., 2015). Penelitian yang dilakukan oleh Leeet al. (2015) pada 30 perusahaan di Korea juga mengidentifikasikan kepuasan kerja memiliki pengaruh positif dan signifikan terhadap OCB.

\section{Implikasi Penelitian}

Implikasi yang didapat dari hasil penelitian ini adalah pihak perusahaan dapat mengetahui bahwa faktor faktor penyebab karyawan memiliki sikap untuk membantu rekan yang lain atau perilaku extra role disebabkan oleh iklim yang ada di organisasi dan juga kepuasan para karyawan dalam bekerja di perusahaan tersebut. Oleh karena itu maka pihak perusahaan harus dapat meningkatkan kesejahteraan karyawan sehingga karyawan puas dalam bekerja dan akan tercapai teamwork yang baik antar sesama karyawan. Selain itu perusahaan juga dituntut untuk menciptakan iklim psikologis di organisasi agar tercipta komunikasi yang baik dan juga hubungan yang harmonis antar para karyawan demi terwujudnya tujuan perusahaan itu sendiri.Keterbatasan dalam penelitian ini adalah indikator dalam penelitian masih terbatas dan selanjutnya diperlukan penelitian lagi dengan data longitudinal untuk mendapat hasil yang lebih baik.

\section{SIMPULAN DAN SARAN}

\section{Simpulan}


Kepuasan kerja dipengaruhi secara positif serta signifikan oleh variabel iklim psikologis. Semakin baik terciptanya iklim psikologis karyawan maka tingkat kepuasanterhadap pekerjaan juga semakin tinggi. Iklim psikologis memiliki pengaruh positif dan signifikan terhadap OCB. Hal ini berarti bahwa semakin baik iklim psikologis karyawan di perusahaan maka hal ini dapat memunculkan perilaku extra role atau OCB yang dapat memaksimalkan kinerja perusahaan tersebut.Kepuasan kerja berpengaruh positif dan signifikan terhadapOCB. Hal ini berarti bahwa semakin tinggi tingkat kepuasan kerja yang dirasakan karyawan di perusahaan maka akan berdampak pada perilaku OCB karyawan atau extra role seperti membantu rekan kerja, atau berpartisipasi pada setiap acara perusahaan maupun perilaku positif lainnya.

\section{Saran}

Berdasarkan analisis yang telah dilakukan dan simpulan yang diperoleh maka dapat dikemukakan saran sebagai berikut bagi perusahaan, disarankan agar lebih memperhatihan iklim yang timbul di organisasi seperti iklim psikologis karena dengan memperhatikan hal tersebut, perusahaan akan dapat membuat iklim yang kondusif dan positif yang nantinya membuat karyawan untuk puas terhadap pekerjaannya sendiri maupun terhadap perusahaan tempatnya bekerja. Saran yang kedua yaitu untuk lebih sering mengadakan kegiatan bersama para karyawan seperti outbond, games, atau event tertentu yang dimana akan membuat para karyawan akan semakin akrab dengan pimpinan serta dengan rekan kerja mereka. Saran yang ketiga yaitu pihak perusahaan menekankan pada karyawan untuk menumbuhkan rasa kepedulian terhadap sesama rekan kerja yang dimana hal ini 
dapat membantu karyawan untuk bekerja sama maupun membantu karyawan lain dalam menyelesaikan pekerjaannya dengan inisiatif sendiri.

\section{REFERENSI}

Aldag, R., and Reschke, W. (1997). Employee Values Added: Measurings Discretionary Effortt and Its Values. Center for Organization Effectiveness, 80(7), : 121-134.

Allison, B.J., Voss, R.S. and Dryer, S. (2001). Students classroom and career success: The role of Organizational Citizenship Behavior. Journals of Education for Busines, 76(5), : 282-289.

Andriani, Gita, dkk. (2012). Organizationals Citizenship Behaviors dan Kepuasan Kerja Pada Karyawn. Fakultas Psikologi Universitas 17 Agustus 1945 Surabaya. Jurnal Penelitian Psikologis, 03 (1), : 341-345.

Angelina, A., dan Subudi, Made. (2014). Pengaruh Kompensasi Finansial dan Gaya Kepemimpinan Terhadap Kepuasan Kerja Karyawan dan Organizational CitizenshipsBehavior (OCB Pada Hotel Alit Beachs, Bali. E-Jurnal Manajemen Universitas Udayana, 3(4), : 1035-1049.

Azeem, S. M. (2010). Job Satisfaction and Organizational Commitment Amongs Employe in the Sultanates of Oman. Psychology, 1 (4), : $295-300$.

Aziri, B. (2011). Job Satisfaction: Literatur Review. Management Researchs and Practice vol. 3 (4), : 77-86.

Biswas, S. and Varma, A. (2007). Psychological Climate and IndividualPerformance in India : Test of a Mediated Model. Employee Relations,29 (6), : 664-676.

Brown, S. P., \& Leigh, T W. (1996). A New Look at Psychological Climate and Its Relationship to Job Involvement, Effort and Performance.Journal of Applied Psychology, 4 (4), : 358-368.

Davis, K., \& Newstorm, J.W. (1996). Perilaku dalam Organisasi, Terjemahan Agus Dharma. Jilid I. Jakarta: Penerbit Erlangga

Diaksa, Ida Bagus Try Dharma dan Dewi, A.A. Sagung Kartika. (2014). Pengaruh kompensasi finansial, kepemimpinan transformasional, dan kondisi lingkungan kerja fisik terhadap kepuasan kerja karyawan pada PT. Wahyu Utama Lestari. E-Jurnal Manajemen Universitas Udayana. 3(9), : 27272744. 
Dole, Carol and Schroeder, Richard G. (2001). The Impact of Varios Factors on the Personality, Job Satisfaction and Turn Over Intentions of Professional Accountants. Managerial Auditing Journal, 16 (4)

Eisele, Per andAlessia D'Amato. (2011). Psychological Climate and Its Relation toWork Performance and Well-being: The Mediating Role of Organizational Citizenship Behavior (OCB). Baltic Journal of Psychollogy, 12 (2), : 4-21.

Fatimah, Amiraa and Halim. (2011). The relationships between organizational justice, organizational citizenship behavior and job satisfaction. Pertanika Journal of Social Science \& Humanity, 19(5), : 115-121.

Garay, Hannah Dara Vanzuela, (2006). Kinerja Extra-Role dan Kebijakan Kompensasi," SINERGI, Kajian Bisnis Dan Manajemen, 8 (1), : 33-42.

Hassan, Masood., Ammara Akram and Sana Naz. (2012). The Relationship between Person Organization Fit, Person-Job-Fit and Turnover Intention in Banking Sector of Pakistan: The Mediating Role of Psychological Climate. International Journal of Human Resource Studies, 2 (3),: 21623058 .

Hasibuan, Melayu. (2012). Manajemen Sumber Daya Manusia. Edisi Revisi. Cetakan Keenam belas. Jakarta : PT Bumi Aksara. Jakarta

Kahn, W. A. (1990). Psychological condition of personal engagement and disengagement at work, Academic of Management Journal, 33, : 992-724.

Koesmono H. Teman, (2005). Pengaruh Budaya Organisasi terhadap Motivasi dan Kepuasan Kerja serta Kinerja Karyawan pada Sub Sektor Industri Pengolahan Kayu Ekspor di Jawa Timur, Disertasi Universitas Airlangga, Surabaya.

Krietner, R. \& Kinicki, R. (2004).Organizational Behavior, 6th edition. New York:McGrawHill

Lee, U. H., Kim, H. K. and Kim, Y. H. (2013). Determinants of organizational citizenship behavior and its outcomes. Global Business and Management Research: An International Journal, 5(1), : 54-65.

Lovell, Sharon E. (1999). Does Gender Affect the Link Between Organizational Citizenship Behavior and Performance Evaluation. http://www.findarticles.com/cf_0/m2294/1999_Sept/58469481/print.jhtm 1.

Lu, C., Shih, Y. dan Chen, Y. (2013). Effects of emotional labor and job satisfaction on organizational citizenship behaviors: a case study on 
business hotel chains.International Journal of Organizational Innovation. 5 (4),: 165-176.

Luthans, F. (1998). Organizational Behavior. McGraw-Hill.

Luthans, F. (2006).Perilaku organisasi, Organizational behavior, Edisi ke 10, Yogyakarta, Andi.

Nunnally, (1967) dalam Ghozali, I, (2011). Aplikasi Analisis Multivariate Dengan Program SPSS. Badan Penerbit Universitas Diponegoro, Semarang.

Organ, D. W. (1988). Organizational Citizenship Behavior : The Good Soldier Syndrome. Lexington, M : Lexington books.

Osman, A., Othman, Y.H., Rana, S.M.S., Solaiman, M. dan Lal, B. (2015). The influence of job satisfaction, job motivation and perceived organizational support towards organizational citizenship behavior (ocb): a perspective of American-based organization in Kulim, Malaysia. Asian Social Science, $11(21) .: 174-182$

Parker C.P, Baltes BB, Young, Scott., Robert A., Huff JW., Lacost HA, and Roberts JE. (2003). Relationship between psychological climate perception and work outcome a meta-analytic review. Journal of organizationalbehavior, 24, : 389-416.

Purbam, D.E. \& Seniati, A.N.L. (2004). Pengaruh Kepribadian dan Komitmen Organisasi terhadap Organizational Citizenship Behavior. Makara, Sosial Humaniora, 8 (3), Desember 2004. 105-111.

Ribeiro, Neuza and Rego, Arménio. (2009). Does Perceived Organizational Virtuousness Explain Organizational Citizenship Behaviors?. World Academy of Science, Engineering and Technology. International Science Index, 3 (6). waset.org/Publication/3212.

Riduwan dan Engkos Achmad Kuncoro. (2012). Cara Menggunakan dan Memakai Path Analysis ( Analisi Jalur ). Cetakan Keempat. Bandung: Alfabeta.

Rivai, Veithzal dan Sagala, Ella Jauvani. (2009). Manajemen Sumber Daya Manusia untuk Perusahaan dari Teori ke Praktik. Jakarta : PT. Raja Grafindo

Robbins, Stephen P. dan Timothy A. Judge, (2008), Perilaku Organisasi.” Buku 1. Edisi 12. Diana Angelica, Ria Cahyani, dan Abdul Muhyi. Jakarta: Salemba Empat. Sekaran, Uma, 2003. Research Methods for Business. Danver: John Willey \& sons, Inc. 
Seniati, Liche. (2006). Pengaruh Masa Kerja, Trait Kepribadian, Kepuasan Kerja, dan Iklim Psikologis terhadap Komitmen Dosen pada Universitas Indonesia. Makara, Sosial Humaniora,10 (2), 88-97

Shadur Mark A., Kienzle Rene, \& Rodwell John J., (1999), “The Relationship between Organizational Climate and Employee Perceptions of Involvement: The Importance of Support", Group \& Organization Management, 24 (4),: 479-503.

Solomon, George T., Winslow, Erik K., Tarabishy, ayman. The role of climate in forstering innovative behavior in enterpreneurial SMEs.

Sudaryono. (2011). Statistika Probabilita. Tangerang : CV Andi Offset.

Sugiyono. (2016). Metode Penelitian Pendidikan Pendekatan Kuantitatif, Kialitatif dan $R \& D$. Bandung: Alfabeta.

Wiratna, Sujarweni. (2015). Metode Penelitian Bisnis dan Ekonomi. Yogyakarta: Pustaka Baru Press.

Sweeney,P.D., \& McFarlin, D.B. (2002). Organizational Behavior : Solution for Management. New York : McGraw Hill

Swift, C. O., \& Campbell, C. (1998). Psychological Climate : Relevance For Sales Managers And Impact On Consequent Job Satisfaction. Journal Of Marketing Theory and Practice. 6 (1), : 27-37.

Tampubolon, Robert. (2004), Risk Management. Jakarta: PT Elex Media Komputindo.

Tobing, Diana Sulianti K. L. (2009). Pengaruh komitmen organisasional dan kepuasan kerja terhadap kinerja karyawan PT. Perkebunan Nusantara III di Sumatera Utara. Jurnal Manajemen dan Kewirausahaan. 11 (1),: 31-37.

Tranggono, Rahadyan Probo dan Andi Kartika. (2008). Pengaruh komitmen organisasional dan profesional terhadap kepuasan kerja auditor dengan motivasi sebagai variabel intervening. Jurnal Bisnis dan Ekonomi. 15 (1): 80-90.

Utama, Made Suyana. (2011). Aplikasi Analisis Kuantitatif. Edisi Kelima. Diktat Kuliah pada Fakultas Ekonomi Universitas Udayana.

Waspodo, Agung dan Lussy, Minadaniati. (2012). Pengaruh Kepuasan Kerja dan Iklim Organisasi terhadap Organizational Citizenship Behavior (OCB) 
E-Jurnal Manajemen, Vol. 8, No. 1, 2019: 7253 - 7282

Karyawan pada PT. Trubus Swadaya Depok. Jurnal Riset Manajemen Sains Indonesia, 3 (1)

Wibowo. (2013). Perilaku Dalam Organisasi Ed ; 1. Jakarta : Rajawali Pers.

Yekty, Rakhesma Pasaty. (2006). Analisis Pengaruh Iklim Psikologis Terhadap Keterlibatan Kerja dan Kepuasan Kerja dalam Meningkatkan Kinerja Karyawan (Studi pada. PT. Coca Cola Bottling Indonesia Central Java Semarang). Thesis program Pascasarjana Universitas Diponegoro, Semarang. 